\title{
'So, What is Wrong with Indigenous Education?' Perspective, Position and Power Beyond a Deficit Discourse
}

Greg Vass

School of Education, The University of Queensland, St Lucia, Australia 4072

Email: g.vass@uq.edu.au

\begin{abstract}
It is the aim of this article to provoke debate and encourage greater scrutiny regarding the use and meaning of the expression 'Indigenous education' within the discursive practices, research and policy in Australian education. Drawing on Hall's (2007) development of ideas from Foucault that give rise to 'Indigenous education' being viewed as a 'regime of truth', it is my contention that the wide-spread and largely uncritical use of this expression is contributing to sustaining deficit assumptions regarding the engagement and outcomes of Indigenous students within Australian schools. To explore this concern, I will firstly 'archaeologically' excavate (Scheurich, 1997) the emergence of this 'regime' within the Australian setting. Following on from this, I will discuss and reflect upon recent debates associated with initiatives designed to 'close the gap' when comparing Indigenous and non-Indigenous student achievements in education. Given the changes inaugurated by the Labor led 'Education Revolution' since 2007, this is a particularly pertinent line of inquiry to take up, with the focus of this paper largely concerned with its impact in the Queensland setting.
\end{abstract}

Keywords: Indigenous education, discourse, close the gap, policy, CRT, power

\section{Introduction}

Recent policy, assessment and curriculum developments within the educational landscape in Australia have contributed to a renewed focus on the academic achievements of Indigenous learners within schools - particularly when compared with the broader student population. Expansively discussed in policy and practical terms as 'Indigenous education', all too often it is framed and positioned as a 'problem' that needs 'fixing'. The approach taken here accepts the view that policy 'problems' such as this are better understood as socially constructed, and from this, that it is pertinent to investigate the 'conditions, assumptions, [and] forces' that are the 'archaeological' basis from which the socially constructed 'problem' emerged (Scheurich, 1997, p. 98).

Already taking up this sort of approach to investigating 'Indigenous education', Martin Nakata (1993, p. 347) drew attention to potential negative consequences that arise from educational policy framed by a 'cultural agenda'. He was critical of the 'disciplinary and disciplining' practices that contributed to constructing the policy 'problem' itself. Expanding on this, Cathryn McConaghy (2000) was concerned with how and why 'culturalism' has framed educational policy focused on Indigenous learners. She called for a better understanding of 'the relationship between racism, discourse, institutions and disciplinary production' (McConaghy, 2000, p. 45). This paper seeks to build on these discussions by critiquing the discursive practices surrounding contemporary uses of, and contributions to the construction of, 'Indigenous education'. 
However, it is not my intention to proffer a definitive explanation of what 'Indigenous education' is or should be. Indeed contrary to this, the paper seeks to problematise the homogenizing forces that have constructed a generic understanding of 'Indigenous education', with particular concern regarding the assumptions and domination of non-Indigenous voices that have contributed to this (Nicoll, 2002). Further highlighting this concern, the prominent contributions of Chris Sarra and Noel Pearson will also be considered, as their Indigenous perspectives, position and authority add further complexity to 'Indigenous education' as a 'regime of truth'.

Following this introduction, I will briefly explore the circumstances and questioning that led to my interest in the 'archaeological' (Scheurich, 1997) foundations that are the basis of my concerns with current understanding/s and uses of 'Indigenous education'. Attention will then turn to excavating the conditions and discourses that have contributed to the emergence of 'Indigenous education' as a 'regime of truth'-as read through Hall's (2007) take up of Foucault. The subsequent discussion is organised into four sections: confusion within education research agendas; the growing profile of the 'regime'; the hidden significance of 'race'; and lastly the limits of discursive 'innocence'. The discussion section of the paper is informed by ideas from critical race theory, an approach that I would argue has much to offer in critiquing the discursive regime, 'Indigenous education'. In concluding, I will return to consider potential avenues warranting further attention that may help with steering 'Indigenous education' away from the deficit landscape it appears entrenched within.

\section{A Reflexive Positioning}

Discourses are ways of talking, thinking, or representing a particular subject or topic. They produce meaningful knowledge about that subject. This knowledge influences social practice, and so has real consequences and effects.

Discourses....always operate in relation to power-they are part of the way power circulates and is contested. The question of whether a discourse is true or false is less important than whether it is effective in practice. When it is effectiveorganizing and regulating relations of power (say, between the West and the Rest) —it is called a 'regime of truth (Hall, 2007, p. 58).

'So, what is wrong with Indigenous education then?' Anna provocatively asked. I had recently met her at a family BBQ, and she had just finished explaining that in her opinion, 'Indigenous education' seems to receive a 'lot' of media attention, a 'lot' of money is put into 'closing the gap', and 'not a lot' of improvement seems to have occurred. Underpinning her views were colour-blind assumptions that society is a 'level-playing field' in which individual merit and effort naturally surmounts systemic challenges (Dixson \& Rousseau, 2006; Gillborn, 2008; Taylor, 2009). This discursive practice not only displaces concerns with the socio-historical foundations of the educational disparity, it is also critical of Indigenous people for receiving additional support in comparison with other 'Aussie battlers'. Thus, social exchanges like mine with Anna, expose the operation of discursive practices such as those described by Hall (above), enabling 'Indigenous education' to be understood as a discursive formation that has material qualities, having 'real consequences and effects', and therefore warranting closer inspection. Drawing on Hall's understanding of Foucault in this way, 'Indigenous education' can be viewed 
as a 'regime of truth' that is girded by deficit assumptions, drawing attention to ongoing concerns with perspective, position and power within the broader Australian landscape.

'Indigenous education' is shaped by multiple supporting and competing discourses (Foucault, 1969), giving rise to tensions and uncertainties regarding authority (which voices should be heard and privileged) and agreement (about what action should be taken and how). It is an area of interest to me, for as I move further into my doctoral research I am increasingly troubled by assumptions that seem to underscore its construction, uses, and the contexts in which it appears. As intimated in my conversation with Anna, the media has contributed to (re)establishing 'Indigenous education' as a maligned discourse in the eyes of some in the public sphere. Recently the attention of politicians and policy makers has also shifted towards this area, with the commitment to 'close the gap' part of a broader federal agenda in education. A corollary of this is a renewed academic concern - including myself — as researchers seek explanations and solutions, and teacher education providers scramble to respond to the need of preparing teachers for 'Indigenous education'. Indicative of this, the University of Queensland offered a compulsory pre-service education subject with this focus for the first time in 2011. Lastly, and most significantly, there are the people represented by the discursive regime itself. Whether through self-identifying or being categorised ('Othered'), Indigenous people are centrally caught up as both objects and participants in the mire of 'Indigenous education'.

Despite being linked by a common concern with ameliorating Indigenous 'disadvantage', an effective, sustainable and widely applicable response to the challenges of improving the achievements and engagement of Indigenous learners is yet to occur. A point acknowledged in the introduction to Closing the gap on Indigenous disadvantage (Department of Education and Training, 2009, p. 4), with the government conceding that despite 40 years of policies and programs, 'Indigenous people remain amongst the most disadvantaged [sic] Australians'. This seemingly inherent deficit framing raises a number of worries for me as an as an early-career researcher. I am anxious about the trope itself and what appears to be the absence, or at the least marginalizing, of an alternative discourse that I can draw from and position myself within. While it is my aspiration to locate an education researcher position and perspective beyond the deficit paradigm, it is not clear (to me) what this discursive terrain might look like? What sort of discursive practices will movement into this terrain require? And how, as a non-Indigenous teacher-researcher, can I navigate a pathway with Indigenous teacher-researchers that will lead to suitable socio-political positionings within this discursive terrain?

\section{Contextualising 'Indigenous Education' in Australia}

\section{Identity, Categories and Authority}

As a non-Indigenous person I have no basis from which to offer a definition of who is, or what it means to be, Indigenous. To attempt to do so would be to act upon the white power that saturates the Australian (educational) landscape. Whiteness in this usage is a way of talking about political and legal frameworks that are grounded in the ideologies of Western 'supremacy' and the impact of colonialist processes (Taylor, 2009, p. 4). In addition to this concern, such a move would naively assert that identities are in some way fixed and discrete (Trigger \& Dalley, 2010). However, and here is the quandary, it is the 'Indigenous' part of 'Indigenous education' that defines and sets this discourse apart from more general education discourses; thus it must be 
accounted for in some way. Foley (2010, p. 171), who identifies himself as Indigenous, refers to the three-part common law definition of a person who: is of Aboriginal or Torres Strait Islander descent; identifies as an Aboriginal or Torres Strait Islander person; and is accepted by the community in which they live (ATSIC, 1998, as cited in Foley, 2010, p. 171). While this may seem reasonable in many respects, the common law definition is limited and limiting, as was shown to me by Jared, a Year 9 student in my class a few years ago, who, despite full-filling two parts of the definition, chose not to identify as Indigenous. He expressed a view that it was racist to suggest that he was, resented the request on school-related paperwork that asked him to identify himself as Aboriginal, and was actively hostile toward the academic support that he felt was imposed on him by the school and his parents. The worry here, is that while Jared chose not to identify as Indigenous at this time and place in his life, he was still categorised in this way and treated in ways that reveal concerns with power. In this sense, I am in agreement with Lucas and Beresford (2010, p. 34) who point out, 'if one is interested in power or in effects of discrimination, the key question concerns not one's racial identity but, instead, the categories in which one is placed by others.'

It is not the aim of this paper to explore the identity politics that underlie the emergence of 'Indigenous' identity per se. For this line of inquiry, Hacking's (1995) conceptualisation of 'looping effects' offers an insightful understanding of the interplay between categories and the effects arising from being categorised - a point of interest beyond the scope of this discussion. My concern is directed towards how and why 'Indigenous' is used as a category that is a 'technology of governance' (Lingard, 2010), with its meaning and use decided upon by the state for the purpose of aggregating populations of students, measuring improvements, allocating resources and developing policy (for example). The authority of the state to define or frame categories such as 'Indigenous' is highly problematic however, as it racialises the category, a result of 'histories of exclusion, deprivation, stigma and racism' (Lucas \& Beresford, 2010, p. 38). A brief look at a few recent examples of governmental uses of 'Indigenous' as a category hints at this racialisation, while also revealing the blurring of a relational (us/them; white/black binary) understanding of Indigenous identities with that of an essentialised criteria based view (Trigger \& Dalley, 2010):

1. Closing the gap on Indigenous disadvantage: The challenge for Australia (Department of Education and Training, 2009) does not clarify who or what is meant by 'Indigenous', hence the policy appears to assume that Indigenous people are a known and identifiable group;

2. The Indigenous education action plan draft: 2010-2014 (MCEECDYA, 2010) explains that 'Indigenous' refers to Aboriginal and Torres Strait Islanders, maintaining an assumed understanding of who is or isn't 'Indigenous';

3. The Australian Bureau of Statistics (ABS) National Aboriginal and Torres Strait Islander social survey (2008) explains that 'Indigenous' refers to, 'persons identified as being of Aboriginal, Torres Strait Islander or both Aboriginal and Torres Strait Islander origin.' Worryingly, the use of origin in this way walks a fine line with regard to reinscribing racist perspectives of Indigenous peoples as being somehow 'pre-modern'; and, 
4. The My School website offers clarification of this definition by explaining that “origin' is considered to relate to people's Australian Aboriginal or Torres Strait Islander descent and for some, but not all, their cultural identity.' Importantly the shift recognizes the right to self-identify, however it remains problematic as the addition of 'descent' hints at a biological, and thus a more overt, racialised reading of the category. Moreover, concerns with the negative consequences arising from 'cultural' constructions of this category have been critiqued for nearly 20 years now (see McConaghy, 2000; Moreton-Robinson, 2004b; Nakata, 1993). The My School website provides information such as demographic and achievement data for individual schools. For a discussion of potential problems arising from this in relation to 'Indigenous Education' see Lingard, Creagh and Vass (2012).

Despite the attempts at improvement shown across these approaches, the framing of 'Indigenous' (on the My School site in particular) also alludes to limitations, as some students may choose not to self identify (as was Jared's request), resulting in a weakening of the veracity of the category for the purposes of data collection and resource allocation. So, while arguably more suitable and culturally sensitive, this approach undermines the purpose for which the category as a 'technology of governance' was created.

\section{Locating 'Indigenous Education'}

For this discussion, the 1967 referendum marks a significant turning point as it led to Aboriginal and Torres Strait Islanders being recognised in the Australian Constitution. This inaugurated movement away from policies of exclusion and assimilation that had previously characterised the experiences of Indigenous students within education (Beresford, 2003). The referendum enabled the federal government to develop national policies and some form of direct intervention (largely in the form of funding) to influence the delivery of education to Indigenous students. Up to this time, a paucity of available, cohesive and relevant national data had contributed to masking the cumulative and wide-spread negative effects arising from prior policies, and thus, had undermined efforts at developing a clear understanding of 'Indigenous education' (Malin \& Maidment, 2003, p. 87). This continued, with issues around data collection identified as a concern in Mellor and Corrigan's (2004) review. They suggested that (national) testing may help redress 'gaps' in understanding and accountability, a point taken up in Closing the gap on Indigenous disadvantage: The challenge for Australia (Department of Education and Training, 2009, p. 7).

During the 1970s the education of Indigenous peoples developed a national profile. A measure of this was the federal initiative that established the National Aboriginal Education Committee (NAEC), a platform through which Indigenous voices contributed to policy and curriculum debates. However, this generally fell on deaf ears, as State education providers appeared resistant to the self-reflection or critique required to support meaningful change in educational practices or policies. Characteristic of the era, 'schools did not generally regard the problems of their Aboriginal students as an outcome of weaknesses in school organisation or policy; rather, they attributed them to the home background and general living environment of the children' (Beresford, 2003, pp. 57-58). 
This trend continued into the 1980s and eventually led to NAEC (in 1985) outlining a national philosophy and clear set of aims. Importantly, the document also retained recognition of the barriers it perceived as still needing to be overcome, stating that,

By any acceptable educational standard in Australia today the education of Aboriginal people is seriously inadequate. A major reason for this inadequacy is that the educational theories and process used in Australia have been developed by and for non-Aboriginal people. They are largely inappropriate for our people. School and further education authorities must develop an education theory and pedagogy that takes into account Aboriginal epistemology (as cited in Loos \& Osanai, 1993, p. 207).

The significance of the NAEC statement was not lost on politicians at the time, and in 1989 the National Aboriginal and Torres Strait Island Education Policy was released-incorporating many of the NAEC suggestions. Attesting to the import of this policy, it continues to be the centre-piece of the national approach to 'Indigenous education', with the central ideas outlined in 1989 continuing to resonate in documents such as the Melbourne declaration on educational goals for young Australians (2008). In this sense, the policy framework underscoring the education of Indigenous students has remained relatively stable since the mid-1970s. Emphasis has been placed on the importance of culturally appropriate pedagogy; inclusive curriculum; attendance and retention; and calls for increased parental engagement and numbers of Indigenous teachers (Mellor \& Corrigan, 2004; Sarra, 2005).

\section{A negative paradigm}

Importantly, also emerging in the 1960s was a shift away from biological assumptions towards cultural assumptions regarding achievement and ability in schooling (Foley, Levinson \& Hurtig, 2000, pp. 43-44). A move that resulted in an ongoing association between 'Indigenous education' and the deficit paradigm (Harrison, 2007), with the assumed intention of responding to the 'disadvantage' of simply being Indigenous. Describing this manoeuvre, Beresford (2003, p. 27) explains:

A deficit perspective has its foundation in a conservative worldview that Aboriginal people lack the cognitive capacity or environmental stimulation to succeed at school. Although discredited for several decades among informed educationalists, the view persists among some conservative teachers who continue to believe that a lack of adequate preparation for schooling in the home, poor language and literacy skills, and problems of attendance, health and nutrition explain the failure of many Aboriginal children to thrive in school.

Deficit thinking potentially leads to lowered expectations of Indigenous students academically and behaviourally in the classroom; poor education policies that fail to negotiate systemic concerns; and inadequate education research that is responsive to these concerns. Despite McConaghy's (2000, p. xi) discerning investigation of the cultural basis that helps explain this, her ideas remain seemingly overlooked. Compensatory education practices continued according to Whatman and Duncan (2005, p. 125), and were still premised on maintaining a deficient view of Indigenous students, while the school system was assumed to be adequate for the task and 
capable of compensating for student inadequacies. A corollary concern is that school based responses typically continue to benefit teachers by maintaining a 'transmission' style pedagogy that aims to inculcate rules, values and knowledge of relevance to the dominant White society (Ah Sam \& Ackland, 2005, p. 185).

Alternative approaches?

Noel Pearson and Chris Sarra have, recently voiced two provocative, yet very different approaches, in Queensland. In Radical hope: Education and equality in Australia, Pearson explores an education pathway built on a 'back to basics' pedagogy and curriculum, harnessing 'explicit instruction' that is 'based on the principle that there are scientifically established methods of effective instruction' (2009, p. 54). The pedagogy and curriculum that he is advocating are worrying however, because they resemble the assimilationist and deficit approaches that have been historically hostile to Indigenous perspectives and identities. Research out of the USA from Brayboy and Castagno (2009) questions the benefits of this type of approach, particularly with regard to Indigenous peoples, instead they advocate for curriculum and pedagogies that are diverse, socio-politically grounded, critical and what they describe as 'culturally responsive'. Moving in this direction, former school principal and education researcher Chris Sarra's ideas and philosophy for the future of 'Indigenous education' is based around a 'strong and smart' vision that places emphasis on developing positive cultural identity alongside high expectations for all involved in educating Indigenous students. It is worth noting here, that despite the philosophical and political differences in their approaches, and that both have critiqued state education providers historical and ongoing responses with meeting the needs of Indigenous learners, that both Pearson and Sarra are cited in the introduction to the Queensland education policy, Closing the gap: Education strategy (Department of Education and Training, 2009, p. 4). As such, as will be expanded upon later, the contributions from these Indigenous leaders further complicate concerns with perspective, position and power with regards to 'Indigenous education'. Particularly in view of aspirations articulated by the 'Indigenism' movement that involves 'Indigenist scholars' (such as Nakata and MoretonRobinson) speaking back to the epistemological foundations that have constructed (and oppressed) Indigenous peoples (Rigney, 2006).

\section{Discussion}

\section{A Confused Research Agenda}

While there may be widespread support for concerns with 'Indigenous education', in some respects, it is only the support and need for concern that can be agreed upon. Ah Sam and Ackland (2005) refer to 'Indigenous education' as an 'ill-defined and confused' topic with authors sometimes failing to clearly differentiate between the education of Indigenous students, and education about Indigenous peoples, history, heritage and contemporary experiences. Partington (2003) suggests that a desire to view development in linear terms further complicates what is already a complex issue, creating a tendency for 'visionaries' and 'reactionaries' to potentially polarise debates. McConaghy (2000) differentiates Indigenous education as a social institution of colonialism and as an academic institution, with distinguishing and competing 'traditions of knowing' further confusing discursive practices. While Mellor and Corrigan (2004) point out that despite a wealth of research and discussion focused on Indigenous students within remote and/or community contexts, these students actually comprise the minority of Indigenous 
students enrolled in schools overall, raising concerns regarding a tendency to discuss the merit of research that was developed within a specific context and then generalising its applicability for very different contexts. In general then, overarching concerns with the dangers of essentialism and a failure to understand the diverse backgrounds and circumstances of Indigenous students permeate the development of policies, teaching strategies, and education research, hence limiting the effectiveness of responding to the contextually specific needs of many Indigenous students (Altman \& Fogarty, 2010; Partington, 2003).

Exemplifying the challenges for the education research community, a study from O'Rourke, Craven, Yeung and Munns (2008) stated the intention of responding to an empirical data research 'gap'. The study focused on the often-overlooked 'low density Aboriginal school', the setting where the majority of Indigenous students actually attend school. This research positioned itself within a framework of identifying 'the best strategies for inclusive educational practices', selecting students from the top quartile of performing schools with the intention of emphasising 'what works' for Aboriginal students already 'succeeding' in education. The research approach deserves to be applauded for its aspiration to move out of the deficit paradigm. However, ideas from critical race theory (henceforth CRT) helps with revealing concerns that arise from the study, despite its good intentions.

Firstly, is CRT's call to context — as it is hard to envisage the findings' wide applicability across the range of educational settings and complex issues that underpin the disengagement of Indigenous students from mainstream education. In other words, focusing on 'what works' for a successful elite group of Indigenous students displaces a critique or concern with the sociohistorical trajectories that created widespread disengagement and poor outcomes in the first place. Secondly, emphasis on 'culturally inclusive' approaches is dated and paternalistic, in comparison with Brayboy and Castagno's (2009) discussion of 'culturally responsive schooling'. This raises concerns regarding the naturalizing and normalizing of Whiteness and Eurocentrism within education, as the notion of being 'culturally inclusive' retains a sense of the state allowing something from the margins to be included within the dominant mainstream. Lastly, the approach and framing of this research also resonates with CRT's understanding of interest convergence, the idea that non-White interests are advanced when they concurrently benefit White interests. The authors explain that the study will 'contribute to the future well-being of the population as a whole, resulting in wide-ranging social and economic benefits and therefore adding materially to national well being' (O'Rourke et al., 2008, p. 7). This innocuous reasoning denies that an 'education debt' (Ladson-Billings, 2006) is owed to Indigenous people in Australia by encouraging readers to support the research agenda as it will not entail further 'costs' to the broader public. Indeed, the suggestion is that this investment in 'Indigenous education' will enhance White financial security and stability.

\section{Turning the Spotlight on 'Indigenous education'}

'Indigenous education' has found its way into news headlines increasingly in recent times, and in part, this can be attributed to the introduction of the National assessment program - Literacy and numeracy (known as NAPLaN) testing regime. Launched in 2008, the publication of results served to clearly reiterate disparities in academic outcomes when Indigenous students were compared with non-Indigenous. There can be little doubt that the statistics speak of the grave urgency to improve the outcomes and engagement of Indigenous students in education: for 
example, $63.4 \%$ of Year 5 Indigenous students were at or above the national benchmark in literacy and numeracy (compared with 92.6 of non-Indigenous students); and non-Indigenous 2024 year olds are nearly twice as likely to have Year 12 qualifications or equivalent (Prime Ministers Report 2010). In the wake of NAPLAN results going public, the federal government launched Closing the Gap on Indigenous Disadvantage: the challenge for Australia (2009), and drawing directly from this, the Queensland government created the Closing the Gap: education strategy (2009). The response supports what Luke $(2009$, p. 2) has described as a political climate that represents an 'unprecedented moment of ...bipartisan support for a strong focus on reform and renewal in the education of Aborigines and Torres Strait Islanders'.

However, these circumstances invite taking up the suggestion from CRT scholar David Gillborn (2005) of asking who and what education policy (such as 'closing the gap') is for? According to Altman and Fogarty (2010) this policy offers unrealistic targets, fails to respond to contextually specific needs of individuals or communities, and is imbued with continuing assimilationist under-currents. Accepting this critique enables the policy to be viewed as failing to serve the interests or needs of many Indigenous students; indeed, the policy can arguably be viewed as politically motivated by White interests. This reading fits Gillborn's (2008) explanation of policy 'gap talk' being a political strategy that deflects attention from the scale of the educational disparity, whilst concurrently masking incremental improvements. Pholi, Black and Richards (2009, p. 10) are also critical of 'gap talk', they explain how and why the prominence of 'closing the gap' operates as a discursive strategy that highlights the dangers of perspective, position and power:

The defining features of Indigenous Australians according to the close the gap approach are, of necessity, deficits. Performance measurements in closing the gap requires a range of baseline data on what is wrong with Indigenous people. Deficit data then forms the basis of what is known about Indigenous people. This in turn sets the strategic goals for action to fix Indigenous people. Because the deficits are clearly situated within Indigenous Australians, progress is measured by the extent to which Indigenous Australians change for the better, thus insulating existing institutions, systems and power structures from an expectation to change also, or change instead. 'Success' is defined by the extent to which Indigenous Australians conform to a set of pre-determined, measurable characteristics of the nonIndigenous ideal, while 'failure' is any outcome that falls below, or manifests outside the scope of these ideal indicators. The measurement of progress in closing the gap relies on comparable data; there is little use for indicators unique to Indigenous Australians without a comparative dataset from the non-Indigenous population. This means that anything that may be uniquely positive about being an Aboriginal or Torres Strait Islander person is of little relevance to the 'evidence base'.

While this observation is made with regards to 'health and well-being', it is equally astute when considering education. From this, the very notion of 'closing the gap' can be viewed as a strategy to position the non-Indigenous community as the normative bench-mark, an approach that serves to mask underlying assimilationist ideals (Altman \& Fogarty, 2010). This intent is not always masked however. As seen in an article from Karvelas for The Australian, when presenting the 
Closing the Gap Report 2010 to parliament, the Prime Minister offered this advice to the Indigenous community in calling for 'changes in behaviour':

'A call to every person, to every family, to every community: to take care of your children; to take a job when you find one; to create a safe environment; to send your kids to school, pay your rent, save up for a home; to respect good social norms and to respect the law; and to reach out to other Australians,' Ms Gillard said. 'If I speak strongly, it is because I have listened to Indigenous people who do these things already. People like Chris Sarra...people like Noel Pearson'. (Karvelas, 2011 page number).

Disturbingly, these comments appear to sustain deficit assumptions whilst reinforcing assimilationist aspirations. Of salience here is the use of Sarra and Pearson in support of the message, with Gillard drawing on a personal relationship with the prominent Indigenous leaders to legitimate her sentiment. This strategy raises serious questions regarding perspective, position and power in relation to the constructing of 'Indigenous education' as a 'regime of truth'. Of particular concern here is the call to 'respect good social norms and to respect the law'. Should this be read as a call to adopt White social norms and adhere uncritically to a White law that continues to deny Indigenous sovereignty and problematically persecute so many people that remain politically, economically and socially excluded (see Moreton-Robinson, 2004b; DePlevitz, 2007; Gray \& Beresford, 2008)? While I share an interest and concern with improving the lived experiences and opportunities of Indigenous people, I have deep reservations with the implicit meaning behind Gillard's rhetoric. What is she asking Indigenous people to give up? And do Sarra and Pearson actually agree with their names being linked with her ideas in this way?

Curiously, there was not universal critique regarding the implications of publishing NAPLAN data, its links with the My School website, or the additional information made available on this site. Sarra was an advocate, seeing potential positives arising from increased transparency and attention being placed on schools and the broader education system. He explains that,

Publishing attendance rates, literacy results and numeracy results and linking to each school's website provides a rich set of data, evidence that will allow us to plan for future improvement. Fundamentally it will help us move beyond the historically dominant assumption that indigenous [sic] people are broken and need fixing, to a new era in which we seriously contemplate new ways of doing business, in ways that build on the strengths of Aboriginal people (Sarra, 2009, page number).

There is much to agree with in what Sarra suggests here. Data can be very useful with identifying areas of concern and directing resources to meet specific needs. What is less clear, however, is how or why he thinks that the publishing of this data will encourage movement away from deficit assumptions being associated with 'Indigenous education'. Illustrating this concern are comments from Andrew Penfold, a lawyer and banker entrepreneur who established the $S t$ Joseph's College Indigenous Fund and the Australian Indigenous Education Foundation. In 
agreement with seeing the need to defend the My School site and the role it can play with improving 'Indigenous education', he explains that,

You can only find out who is swimming naked when the tide goes out. I cannot see any reason why the same principles advocated by the government and indigenous [sic] educators such as Sarra in support of transparency for the My School website shouldn't be applied specifically for Indigenous students. There are some 10, 000 schools in Australia. All of them should play their part in closing the gap in Indigenous education outcomes. All primary and secondary schools in Australia should be compelled to disclose in My School on an aggregated and anonymous basis and using nationally consistent metrics, the total number and percentage of day and boarding indigenous students in the school, the main communities where those students originate from, information on their NAPLaN results, attendance rates, retention rates, Year 12 attainment rates, post-school destinations and the number of Indigenous staff (teaching and otherwise) at the schools. All this information is readily available without much extra work or funding, it just needs to be made public (Penfold, 2010, page number).

In these comments we see the predilection of Whiteness to offer the veneer of moral reasoning to justify the sentiment. Penfold is implying that if you do not agree with this level of transparency and scrutiny, as a move to help improve 'Indigenous education', then you must in some way be part of the problem or simply unreasonable. The citing of Sarra in support of his argument is again noteworthy, as is speculating about Sarra's response to the level of scrutiny and transparency suggested. Irrespective of this, it is hard to envisage that such ideas would be freely articulated with regard to a white student subsection of the schooling population. Imagine the response if elite private (White) schools such as Geelong Grammar and Sydney Grammar were asked to provide this data! Penfold's views illustrate what Nicoll (2002, add page number) describes as the 'performative assumption of perspective' in reference to the naturalized assumption and dominance of White voices that claim to hold the 'proper perspective'. Nicoll is critical of such views that fail to 'intellectually engage with Indigenous discourse but simply assumes an omniscient position above them' (2002, page number). In agreement with this, perspectives such as Penfold's raise suspicions about the role and significance of race-based assumptions underpinning the discursive formation of 'Indigenous education'.

\section{Concerns with 'Race' in Education}

Research in the 1970s identified race based assumptions and racism as shaping the experiences and disengagement of Indigenous students in education (Beresford, 2003, p. 59). Yet nearly 20 years later, Nakata (1993) suggested that despite some changes stemming from policies, that inherent racist structures, relationships and pedagogy within the education system were yet to be addressed (as cited in Whatman \& Duncan, 2005, p. 134). Malin and Maidment (2003, p. 92) also cite racism as a significant concern, while Lampert $(2005$, p. 92$)$ refers to research that suggests the impact and influence of teachers' racialised identities continues to be a significant contributing factor explaining poor attendance and retention of Indigenous students in education. Emphasising the point that 'race' evidently remains a 'very real social and personal issue' that has tangible effects within educational settings in Australia (Lampert, 2005, p. 92). In summarizing this point, Gray and Beresford (2008, p. 207) explain that: 
Since the 'discovery' of educational disadvantage in the late 1960s governments have been engaged in a wide variety of reform measures but there has been little acknowledgment given to the ongoing place of racist assumptions and ideas in this process. Similarly, there has been little acknowledgment of the effect these ideas have had on underpinning the current slow progress in Indigenous education.

Disturbingly, acknowledging the pervasive influence of negative race-based assumptions within education is not universally taken up. Recent examples of this include Mellor and Corrigan (2004) giving scant attention to the effects of 'race'; Hughes and Hughes (2009, p. 7) naively reductive assertion that 'schools, not ethnicity determine outcomes'; and while Pearson (2009) is prepared to concede the presence of racism, he emphasizes the importance of taking up a 'no excuse' approach to education that downplays the significance of it. The silencing and marginalising of 'race talk' in this way is (at the very least) a disservice that enables the material effects arising from racism to be displaced or ignored (Delpit, 1995).

Contrary to this, concerns regarding the impact of 'race' appear to extend deeply within the systemic operation of education. Ah Sam and Ackland (2005, p. 191) refer to a 2001 Queensland Anti-Discrimination Commission report that found teachers were amongst the 'direct perpetrators' of widespread racism occurring in Queensland schools. Also raising awareness of this issue, De Plivitz (2007) is critical of the 'apparently race-neutral educational polices' that fail to be relevant or adequate in responding to the actual 'disadvantage' [sic] experienced by many Indigenous students in education. She argues that this practice, acknowledged in the law as 'indirect discrimination', is linked with systemic racism that is prevalent in Australian education and goes a long way to identifying one of the 'hidden barriers' that curtail the success of Indigenous students in education (2007, p. 55). A view supported by findings from a 2003 steering committee on 'Indigenous education' (led by Sarra), which was critical of the limited impact of successive policies, and amongst a raft of suggested 'accountability measures', challenged the education system's apathetic 'mind-set' regarding the implicit acceptance of institutionalised racism and the maintenance of a deficit paradigm permeating the provision of education to Indigenous students (Sarra, 2005, p. 256). These contributions highlight the relevance of CRTs assertion that issues with race remain endemic in settings such as Australia, and hence warrant far greater attention than currently is received (Moreton-Robinson, 2004b; Gillborn, 2008; Taylor, 2009) Clearly, there is a distinct impact on the experiences and engagement for Indigenous students in educational settings arising from race-based assumptions.

\section{'Indigenous Education' is not Neutral}

It has been the intention of this paper to map out the development of 'Indigenous education' as distinct from what is typically understood as mainstream schooling. Additionally, the paper has raised concerns that underpinning this perspective are assumptions that 'Indigenous education' is viewed as a 'problem' when compared with mainstream (read as White) education. From this, it has been suggested that 'Indigenous education' has been constructed in ways that largely serve non-Indigenous purposes. And lastly, the ongoing impact of negative race-based assumptions was raised as an issue that warrants greater attention. The discourses that have dominated the construction of 'Indigenous education' can therefore, be viewed as far from 'neutral'. In taking up Moreton-Robinson's (2004a) provocative arguments, I share concerns regarding the emergence of 'Indigenous education' and what it reveals about relationships, power, knowledge and representation in the Australian setting. A point that returns to consideration of 'Indigenous 
education' as a 'regime of truth' and the different voices that contribute to its production within the broader socio-political Australian context. A necessary shift for reflecting on issues linked with position and perspective, and which in turn helps with developing a deeper appreciation of how power is deployed, and its links with inequities. What follows returns to Stuart Hall's (2007) challenge to consider the 'innocence' of discourse, a step that reiterates grave concerns regarding the discursive processes and practices that underpin and sustain 'Indigenous education'.

(a) We draw on what we know and are familiar with to help explain or describe things (Hall, 2007, p.p. 56-57):

Resulting in a tendency for discourse on 'Indigenous education' to be framed by assumptions about curriculum, pedagogy and assessment that derive from non-Indigenous understanding and values of education and 'knowledge'. Evident here with regard to the emphasis placed on NAPLAN data, with achievement on this 'high-stakes' national assessment regime operating as a barometer that measures educational 'success'. The worry is that the assessment instrument appears to not be 'culturally fair' (Klenowski, 2009), with the additional concern that it displaces holistic learning in favour of narrow curriculum and pedagogy that is designed to meet the state mandated targets. Critiquing the effects of similar education policy from the USA, Brayboy and Castagno (2009) argue that No Child Left Behind linked policy with high-stakes testing regimes and resulted in sustaining inequality and discrimination. In short, while non-Indigenous voices dominate the construction of 'Indigenous Education', the curriculum, pedagogy and assessment that many Indigenous students encounter will continue to be White-washed in ways that deny or obscure Indigenous epistemologies, aspirations or the ongoing socio-historical effects of invasion.

(b) We are motivated by particular interests, concerns and/or goals that are potentially contradictory, subconscious and irrational (Hall, 2007, p.p. 56-57):

Leading to efforts that seek to redress 'Indigenous education' as largely driven by a desire to ameliorate 'disadvantage' - the deficit paradigm. Taking up this perspective appeases neo-liberal thinking and guilt, whilst concurrently sustaining the dominance of mainstream non-Indigenous (White) society. This goes a long way to potentially explaining firstly, why many educational responses have failed to overcome entrenched systemic barriers that negatively impact on the learning and engagement of Indigenous students; and secondly, the inadequate or poorly targeted resourcing allocated in support of realizing genuine change. The quest to 'close the gap' illustrates this, as the issue has been rendered a 'technical' problem to 'fix' (Altman \& Fogarty, 2010), with education providers readily able to demonstrate that 'something' is being done, whilst the deficit and assimilationist framing of the policy (hence systemic concerns) remain ignored. In its current form then, the NAPLAN 'data' will rearticulate the 'superiority' of nonIndigenous students, allowing blame to continue being directed towards Indigenous peoples for failing to take advantage of this opportunity (re-read the comments from Gillard as a reminder of what this looks like); and

(c) Those voices with more power are in a position to dominate the discourse and silence or marginalize the less powerful voices (Hall, 2007, p.p. 56-57):

To date, 'Indigenous education' discourse has been dominated by non-Indigenous voices, as the reference list to this article will sadly attest. Resulting in policy, research, curriculum, pedagogy and assessment decision making as largely residing in the hands of White interests. While perhaps a cynical perspective, it is arguably not surprising that there has been minimal improvement in the outcomes or engagement of Indigenous students since the 1960s. However, I 
am curious here about the frequent presence of both Pearson and Sarra in relation to discussions of NAPLAN, My School, Closing the Gap, and 'Indigenous education' broadly - seemingly to the exclusion of any other Indigenous voices. Is it possible that the dominant presence of these two Indigenous leaders contributes to the silencing and marginalizing of alternative Indigenous voices that may offer critiques of these initiatives? It is hard to imagine that these educational responses are met with universal approval within the Indigenous community. Why are these voices acknowledged by the non-Indigenous community the way they are? And if Sarra or Pearson started commenting on non-Indigenous education, would their views be given a similar emphasis?

\section{Concluding Thoughts: 'Indigenous Education' Reconsidered}

The education system in Australia is a socialising process. A kid enters it to be socialized into the dominant norms of the master society, and if he or she does not learn how to play the system, or refuses to participate then it is too bad (Mudrooroo, 1995, p. 113).

The aim of the paper has been to present an argument calling for increased critical awareness on the part of those contributing to 'Indigenous education' discourses; with the challenge of moving beyond protecting White interests and reifying deficit perspectives yet to be meaningfully addressed. Drawing attention to this challenge, in his latest book-written with pre-service teachers as a target audience - respected 'Indigenous education' scholar Neil Harrison discusses the 'search for a solution in Indigenous education'. In the opening chapter he explains:

Many Indigenous students are not convinced that school is worthwhile because they cannot see themselves in the pictures of the future that teachers usually paint for them. They do not understand the significance of what they are expected to learn. Many schools therefore try to make their curriculum culturally friendly for Indigenous students, but this hasn't really worked in terms of improving student outcomes and retention. In the end, teachers make a decision about whether they are with or against Indigenous people, or alternatively, they may not care one way or the other. But remember, the kids will be influenced by the decisions you make. You will never be able to hide your thoughts and values from them, so what you think really counts (Harrison, 2008, p. 12).

While the sentiment is commendable, my anxiety stems from the continuance of framing this within 'Indigenous education' at all. It is a statement that is equally true when considering students from a variety of different backgrounds. Harrison is simply describing good pedagogy; it does not have to be framed as good pedagogy for Indigenous students. Teachers making judgments based on essentialist assumptions regarding race, gender, class, or physical ability (for example), will always detract from the teaching and learning experience offered. This then, draws attention to what is perhaps the greatest challenge regarding 'Indigenous education', how does the education community move forward in ways that genuinely support and meet the needs of Indigenous students in ways that do not sustain a deficit perspective? Harrison is inviting prospective teachers to make the moral leap to simply decide to work with Indigenous people, but is this enough? That 'Indigenous education' remains relatively unchanged over the last forty 
years, despite the efforts of many that do want to work with Indigenous people, would suggest to me that the approach is not adequate on its own.

If there is an area of the education sector that can, and must be redressed with specific regard to Indigenous students, in agreement with Riggs (2007), Nicoll (2004) and Moreton-Robinson (2004b), I would argue that issues linked with sovereignty must be placed as central to future education research, policy, curriculum and pedagogy agendas. Education is well positioned to play a decisive role in critiquing the historical, social, economic and political narratives and structures that underpin inequitable relationships within Australia. The enduring impact and influence of deficit thinking, assimilationist ideologies, and race-based assumptions are all built on the legacies associated with dispossession and the ongoing denial of Indigenous sovereignty. It is the uncritical production, re-production and dissemination of the 'knowledge' that sustains this nexus of domination and urgently demands far greater scrutiny within the educational landscape in Australia.

The challenge then, is for future contributors to 'Indigenous education'-including myself-to respond to Aileen Moreton-Robinson's (2004a, p. 88) rebuke that Whiteness has shaped knowledge production, and from this, that academia must accept that the 'dominant regime of knowledge is culturally and racially biased, socially situated and partial.' Following from this type of self-reflexive critique, education research, teacher education, school-based practices, and policy development can create spaces that will support moving towards enabling teachers to develop an awareness and understanding of how they, and society broadly, experience and are shaped by, racialisation processes. A corollary of this is the potential to foster teachers' appreciation of how and why issues linked with racialised perspectives and positioning impacts on educational practices and processes. Taking up this challenge may enable discourse on 'Indigenous education' to move away from the deficit paradigm by transforming concerns with perspective, position and power within the Australian setting.

\section{Acknowledgments}

I would like to thank Sue Monk, Sam Sellar, Carolynn, Bob and Liz for the support and suggestions they offered during the development of this paper. I would also like to express my appreciation to the supportive and constructive comments made by the reviewers.

\section{References}

Ah Sam, M., \& C. Ackland. (2005). The curriculum: A doorway to learning. In J. Phillips \& J. Lampert (Eds.), Introductory Indigenous studies in education: The importance of knowing (pp182-200). Malaysia: Pearson Education Australia.

Altman, J., \& B. Fogarty. (2010). Indigenous Australians as 'no gaps' subjects: education and development in remote Australia. In I. Snyder \& J. Nieuwenhuysen (Eds.), Closing the gap in education: Improving outcomes in southern world societies (pp 109-128). Clayton, VIC: Monash University Press.

Australian Bureau of Statistics. (2010). National Aboriginal and Torres Strait Islander social survey (2008). Retrieved February 22, 2010, from 
http://abs.gov.au/AUSSTATS/abs@.nsf/Latestproducts/4714.0Main\%20Features12008?opendoc ument\&tabname $=$ Summary\&prodno $=4714.0 \&$ issue $=2008 \&$ num $=\& v i e w=$

Australian Government. (2009). Closing the gap on Indigenous disadvantage: The challenge for Australia. Canberra, ACT: Commonwealth of Australia.

Australian Government. (2010). Closing the gap: Prime Minister's report 2010. Canberra, ACT: Commonwealth of Australia.

Beresford, Q. (2003). 'The context of Aboriginal education' In Beresford, Q. \& G. Partington (Eds.), Reform and resistance in Aboriginal education: The Australian experience, p.p. 10-68. Perth, WA: University of Western Australia Press.

Brayboy, B., \& A. Castagno. (2009). Self-determination through self-education: Culturally responsive schooling for Indigenous students in the USA. Teaching Education, 20(1), 31-53.

Delpit, L. (1995). Other people's children: Cultural conflict in the classroom. New York, NY: New Press.

DePlevitz, L. (2007). Systemic racism: The hidden barrier to educational success for Indigenous school students. Australian Journal of Education, 51(1), 54-71.

Department of Education and Training. (2009). Closing the gap: Education strategy. Brisbane, QLD: Queensland Government.

Dixson, A. \& C. Rousseau (Eds.). (2006) Critical race theory in education: All god's children got a song. New York, NY: Routledge.

Foley, D. (2010). Aboriginality and pedagogies. In R. Connell, C. Campbell, M. Vickers, A. Welch, D. Foley, N, Bagnall \& D. Hayes (Eds.), Education, change and society $\left(2^{\text {nd }}\right.$ ed., pp.168204). South Melbourne, VIC: Oxford University Press.

Foley, D., Levinson, B. \& Hurtig, J. (2000). Anthropology goes inside: The new educational ethnography of ethnicity and gender. Review of Research in Education, 25, 37-98.

Foucault, M. (1969). The archaeology of knowledge. Milton Park, UK: Routledge.

Gillborn, D. (2005). Education policy as an act of white supremacy: Whiteness, critical race theory and educational reform. Journal of Education Policy, 20(4), 485-505.

Gillborn, D. (2008). Racism and education: Coincidence or conspiracy? London: Routledge.

Gray, J., \& Q. Beresford. (2008). A 'formidable challenge': Australia's quest for equity in Indigenous education. Australian Journal of Education, 52(2), 197-223. 
Hacking, I. (1995). The looping effects of human kinds. In D. Sperber, D. Premack \& A. Premack (Eds.), Causal cognition: A multi-disciplinary debate (p.p 351-383). Sixth Fyssen Symposium, held at the Pavillon Henri IV a St-Germain-en-Laye. Oxford: Clarendon Press.

Hall, S. (2007 [1996]). The West and the Rest: discourse and power. Das Gupta, T., James, C., Maaka, R., Galabuzi, G. \& C. Anderson. (Eds) Race and Racialization: essential readings (p.p. 56-63). Toronto, Ontario: Canadian Scholars Press.

Harrison, N. (2007). Secret transmission: Modelling cross-cultural relations in classroom discourses. Asia-Pacific Journal of Teacher Education, 35(1), 41-53.

Harrison, N. (2008). Teaching and learning in Indigenous education ( $1^{\text {st }}$ ed.). South Melbourne, VIC: Oxford University Press.

Hughes, H., \& M. Hughes. (2009). Policy monographs: Revisiting Indigenous education. Australia. The Centre for Independent Studies, CIS Policy Monograph 94, ISBN: 9781864322149.

Karvelas, P. (2011, February 10) 'Gap won't close if you don't act': Julia Gillard. The Australian. Retrieved March 1, 2011, from www.theaustralian.com.au.

Klenowski, V. (2009). Australian Indigenous students: Addressing equity issues in assessment. Teaching Education, 20(1), 77-93.

Ladson-Billings, G. (2006). From the achievement gap to the education debt: Understanding achievement in U.S. schools. Educational Researcher, 35(7), 3-12.

Lampert, J. (2005). The teaching that matters: Merging our personal beliefs with our professional practice in the classroom. In J. Phillips \& J. Lampert (Eds.), Introductory Indigenous studies in education: The importance of knowing (pp.). Sydney, NSW: Pearson Education Australia.

Lingard, B. (2011). Policy as numbers: Ac/counting for educational research. The Radford Lecture, presented at the Australian Association for Research Education, Melbourne University. The Australian Educational Researcher, 38 (4), 355-382.

Lingard, B., Creagh, S., \& G. Vass. (2012). Education policy as numbers: Data categories and two Australian cases of misrecognition. Journal of Education Policy, 27(3), 315-333.

Loos, N., \& Osanai, T. (1993). Philosophy, aims and policy guidelines for Aboriginal and Torres Strait Islander education. In N. Loos \& T. Osanai (Eds.), Indigenous minorities and education: Australian and Japanese perspectives of their Indigenous peoples, the Ainu, Aborigines and Torres Strait Islanders (pp. 206-221). Tokyo: Sanyusha Publishing.

Lucas, S., \& L. Beresford. (2010). Naming and classifying: Theory, evidence and equity in education. Review of Research in Education, 134, 25-84. 
Luke, A. (2009). Introduction: On Indigenous education. Teaching Education, 20(1), 1-5.

Malin, M. \& D., Maidment. (2003). Education, Indigenous survival and well being: Emerging ideas and programs. The Australian Journal of Indigenous Education, 23, 85-99.

McConaghy, C. (2000). Rethinking Indigenous education: Culturalism, colonialism, and the politics of knowing. Brisbane, QLD: Post Pressed.

Mellor, S., \& M. Corrigan. (2004). The case for change: A review of contemporary research on Indigenous education outcomes. The Australian Education Review, Australian Council for Educational Research: ACER Press.

Ministerial Council for Education, Early Childhood Development and Youth Affairs (MCEECDYA). (2009). Indigenous education action plan draft: 2010-2014. Retrieved January 11,2012 , from http://www.mceetya.edu.au/verve/ resources/IEAP_Stage Two Consultation_Draft (2).pdf

Moreton-Robinson, A. (2004a). Whiteness, epistemology and Indigenous representation. In A. Moreton-Robinson (Ed.), Whitening race: Essays in social and cultural criticism (pp. 75-88). Canberra, ACT: Aboriginal Studies Press.

Moreton-Robinson, A. (2004b). The possessive logic of patriarchal white sovereignty: The high court and the Yorta Yorta decision. Borderlands e-journal, 3(2).

Mudrooroo. (1995). Us mob - History, culture, struggle: An introduction to Indigenous Australia. Sydney, NSW: Angus and Robertson.

Nakata, M. (1993) Culture in education: For us or for them? In N. Loos \& T. Osanai (Eds.), Indigenous minorities and education: Australian and Japanese perspectives of their Indigenous peoples, the Ainu, Aborigines and Torres Strait Islanders (pp. 334-349). Tokyo: Sanyusha Publishing.

Nicoll, F. (2002) De-facing terra nullius and facing the public secret of Indigenous sovereignty in Australia. Borderlands e-journal, 1(2). Retrieved from www.borderlandsjournal.adelaide.edu.au/vol1no2_2002/nicoll_defacing.html.

Nicoll, F. (2004) 'Are you calling me a racist?' Teaching critical whiteness theory in Indigenous sovereignty. Borderlands e-journal, 3(2). Retrieved from http://www.borderlands.net.au/vol3no2 2004/nicoll teaching.htm.

O'Rourke, V., R. Craven., A. Yeung \& G. Munns (2008, December). Closing the gap for Aboriginal primary students in low density schools: A multi-method longitudinal analysis elucidating impact of inclusive practices. Unpublished paper presented to the Australian Association for Research in Education conference, Brisbane, Queensland. 
Partington, G. (2003). Conceptual frameworks for Indigenous education: Review and analysis. In S. McGinty (Ed.), Sharing success: An Indigenous perspective - A collection of papers from the $2^{\text {nd }}$ National Australian Indigenous Education Conference, 2002 (pp.101-128). Altona, VIC: Common Ground.

Pearson, N. (2009). Radical hope: Education and equality in Australia. (Quarterly Essay). Melbourne, VIC: Black Inc.

Penfold, A. (2010, February 26). Gillard's schools site should be used to help close the gap. The Australian. Retrieved March 1, 2011, from www.theaustralian.com.au

Pholi, K., D. Black. \& C. Richards. (2009). Is 'close the gap' a useful approach to improving the health and wellbeing of Indigenous Australians? Australian Review of Public Affairs, 9(2), 1-13.

Riggs, D. (2007). Introduction: Critical race and whiteness studies in a postcolonising nation. In D. Riggs, (Ed.), Taking up the challenge: Critical race and whiteness in a postcolonising nation (pp.1-16). Adelaide, SA: Crawford House.

Rigney, L. (2006). Indigenist research and Aboriginal Australia. In J. Kunnie \& N. Goduka (Eds.), Indigenous peoples' wisdom and power: Affirming our knowledge through narratives (pp. 32-50). Farnham, UK: Ashgate Publishing.

Sarra, C. (2005). Strong and smart: Reinforcing Aboriginal perspectives of being Aboriginal at Cherbourg State School. Unpublished PhD Thesis, Murdoch University. Retrieved October 11, 2010, from http://wwwlib.murdoch.edu.au/adt/browse/view/adt-MU20100208.145610.

Sarra, C. (2009, November 25). Website will shine light on indigenous schools. The Australian. Retrieved March 1, 2011, from www.theaustralian.com.au.

Scheurich, J. (1997). Research method in the postmodern. London: The Falmer Press.

Taylor, E. (2009). The foundations of critical race theory in education: an introduction. In E.

Taylor, D. Gillborn \& G. Ladson-Billings (Eds.), Foundations of critical race theory in education (pp. 1-13). New York, NY: Routledge.

Trigger, D., \& C. Dalley. (2010). Negotiating Indigeneity: Culture, identity and politics. Reviews in Anthropology, 39, 46-65.

Whatman, S., \& Duncan, P. (2005). Community participation in Indigenous education: Learning from the past, in policy and practice. In Phillips, J. \& J. Lampert (Eds.) Introductory Indigenous studies in education: The importance of knowing (pp. 117-138). Frenchs Forest, NSW: Pearson Education Australia.

\section{About the Author}

Greg Vass is currently a full-time PhD candidate in the School of Education at The University of Queensland. His research is concerned with how educational practices and processes have 
contributed to sustaining achievement and engagement disparities between Indigenous and nonIndigenous learners. Prior to this he worked as a secondary school social science teacher for several years. 